\title{
Perancangan dan implementasi alat pemantauan dan pengendalian pada aquascape berbasis internet of things.
}

\author{
Muhammad Rosyid ${ }^{* 1}$ dan Catur Iswahyudi ${ }^{2}$ \\ 1 Informatika IST AKPRIND Yogyakarta \\ Jl Kalisahak Komplek Balapan 28 Yogyakarta \\ muh.rosyid95gmail.com \\ 2 Informatika IST AKPRIND Yogyakarta \\ Jl Kalisahak Komplek Balapan 28 Yogyakarta \\ catur@akprind.ac.id
}

\begin{abstract}
Abstrak
Berdasarkan survei lapangan, sistem aquascape yang ada dipasaran saat ini memang sudah menarik, dengan berbagai koleksi tumbuhan dan ikan, namun salah satu permasalahan yaitu dalam pemeliharaan aquascape yang masih manual. Saat pemilik aquaspace pergi dalam jangka waktu yang lama maka bagaimana menjaga kondisi penerangan dan kualitas air menjadi sebuah masalah tersendiri. Penggunaan sistem berbasis internet of things untuk melakukan pemantauan terhadap keadaan aquascape dari jarak jauh memungkinkan dilakukan. Sebuah prototipe yang dirancang untuk mengendalikan penerangan dan memantau kondisi air pada aquascape melalui web dilakukan dalam penelitian ini. Mikrokontroler Arduino dan NodeMCU serta sistem basis data Firebase digunakan dalam penelitian ini untuk membaca dan menyimpan data dari sensor yang digunakan. Dari hasil pengujian prototipe dalam melakukan pengendalian penerangan lampu pada aquascape sudah dapat bekerja sesuai yang diharapkan. Pemberian perintah kontrol terhadap lampu dilakukan dari jarak jauh melalui website berhasil sesuai dengan rencana pengujian. Hasil pengujian dari kinerja sensor pH dan sensor suhu juga bekerja sesuai yang diharapkan yaitu berhasil membaca nilai pH air dan kondisi suhu air. Data yang didapatkan juga telah mampu disimpan dalam basis data Firebase dan ditampilkan pada halaman web. Penelitian ini juga memberikan hasil berupa data waktu delay dari pembacaan sensor ke proses penulisan data di Firebase dan menampilkannya di halaman web. Nilai delay pada pembacaan dari prototipe ke website pada sensor $\mathrm{pH}$ yang didapatkan adalah rata-rata $31,77 \mathrm{~s}$ dan sensor suhu dengan rata-rata delay 33,13 s.
\end{abstract}

Kata Kunci monitor, pH sensor, sensor suhu, website, firebase, iot

\section{Pendahuluan}

Perkembangan teknologi telah memberikan kontribusi yang besar terhadap banyak aspek kehidupan. Salah satu contoh teknologi tersebut adalah sistem yang dapat melakukan pemantauan dan pengendalian dengan memanfaatkan konektivitas jaringan internet dalam mengakses dan mengontrol perangkat dari jarak jauh. Konsep ini sering disebut dengan Internet of thing (IoT) dimana umumnya digunakan untuk mengendalikan peralatan elektronik dari jarak jauh melalui jaringan komputer lokal maupun internet.

Kemajuan teknologi seperti penggunaan IoT tersebut tidak dapat dipungkiri harus bisa dimanfaatkan, dipelajari serta diterapkan dalam kehidupan sehari-hari. Sehingga,

* Corresponding author.

(i) $\odot$ Rosyid. M dan Iswayudi. C;

licensed under Creative Commons License CC-BY
Jurnal Open Access 
dapat memudahkan pengguna seperti untuk memantau ataupun mengendalikan peralatan elektronik, kapanpun dan dimanapun dengan catatan mempunyai jaringan internet yang memadai [1]. Pemanfaat teknologi IoT tersebut saat ini sudah cukup banyak di berbagai bidang, salah satunya adalah untuk pemeliharaan ekosistem dalam aquascape.

Bagaimana kondisi seperti penerangan, pemberian pakan, kondisi dan kualitas air harus diperhatikan saat memiliki aquascape. Kondisi yang harus diperhatikan ini akan menjadi masalah dan sangat merepotkan jika pemilik aquascape memiliki kesibukan yang sangat tinggi terutama saat sering ditinggal, sehingga tidak sempat untuk mengurus atau memelihara aquascape [2]. Pembuatan sebuah rangkaian yang mampu membantu pemeliharaan aquaspace yang dapat dikendalikan dari jarak jauh melalui internet merupakan salah satu solusi yang bisa dikembangkan untuk mengatasi masalah tersebut. Penelitian ini bertujuan untuk membuat prototipe alat yang mampu memantau dan mengendalikan dalam pemeliharaan aquascape melalui halaman web. Pengukuran ketepatan penjadwalan waktu saat menghidupkan lampu, pemantauan kondisi $\mathrm{pH}$ dan suhu air pada aquascape dari jarak jauh atau secara daring berbasiskan web dilakukan dalam penelitian ini.

Penelitan untuk melakukan pengontrolan akuarium atau kolam ikan sudah banyak dilakukan. Seperti dilakukan oleh [3] yang melakukan penelitian untuk memantau kualitas air akuarium ikan hias melalui android berbasiskan mikrokontroler Arduino mega 2560 dan sensor suhu DS18B20. Pengembangan model sistem monitoring berbasis IoT berbiaya rendah untuk memberikan informasi parameter $\mathrm{pH}$ dan kekeruhan air setiap saat kepada pemilik ikan hias dilakukan oleh [4] melalui aplikasi Blynk pada ponsel. Penggunaan sensor probe SEN1069 untuk melakukan pengambilan data dan mikrokontroler Arduino sebagai kontrol dilakukan oleh [5] untuk mengamati tingkat keasaman air. Penggunaan media Telegram untuk melaporkan kondisi tingkat keasaman air dari jarak jauh dengan berbasiskan Arduino juga dilakukan oleh [6]. Demikian pula dengan penelitian [7] yang melakukan pemberian pakan otomatis dan mengamati $\mathrm{pH}$ pada budidaya ikan nila berbasikan IoT dengan aplikasi Blynk dan Arduino.

Dari beberapa pustaka tersebut nampak bahwa telah cukup banyak yang melakukan penelitian berkaitan dengan pemantauan air di akuarium maupun kolam, khususnya dalam pemantuan suhu dan kualitas air. Belum adanya pengendalian penerangan atau cahaya secara daring melalui web yang menjadi salah satu perbedaan penelitian ini. Kebutuhan adanya cahaya dalam aquascape yang harus disinari cahaya dengan durasi maksimum 12 jam per hari dan minimum 5 jam per hari [8] sehingga bagaimana melakukan kontrol terhadap lampu menjadi salah satu tujuan dalam penelitian ini. Penggunaan sistem basis data (Firebase) untuk menyimpan data dari sensor dan menampilkan ke halaman web juga menjadi pembeda dengan penelitan lainnya.

\section{Metodologi}

Penelitian ini merancang prototipe berupa alat pengendalian lampu secara otomatis pada serta melakukan pemantauan terhadap kualitas air malalui parameter $\mathrm{pH}$, dan suhu air pada aquarium. Arsitektur sistem yang digunakan dalam penelitian ini terdiri dari 2 mikrokontroler dan sensor yang sudah saling terhubung satu dengan yang lain. Jaringan wifi digunakan untuk menghubungkan perangkat keras dengan sistem basis data Firebase melalui internet. Rancangan arsitektur sistem pada penelitian ini dapat dilihat pada Gambar 1.

Alur kerja pada prototipe yang digunakan sebagai dasar dalam penelitian ini secara umum tertampil di Gambar 2. Alur kerja dari prototipe yang dilakukan dalam penelitian ini dapat terbagi dua yakni pada perangkat keras dan perangkat lunak. 


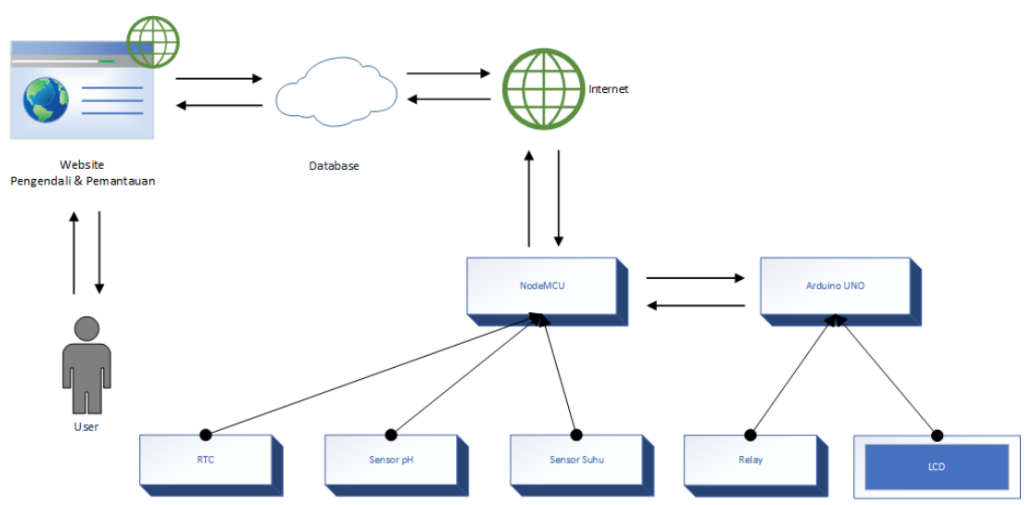

Gambar 1 Arsitektur sistem

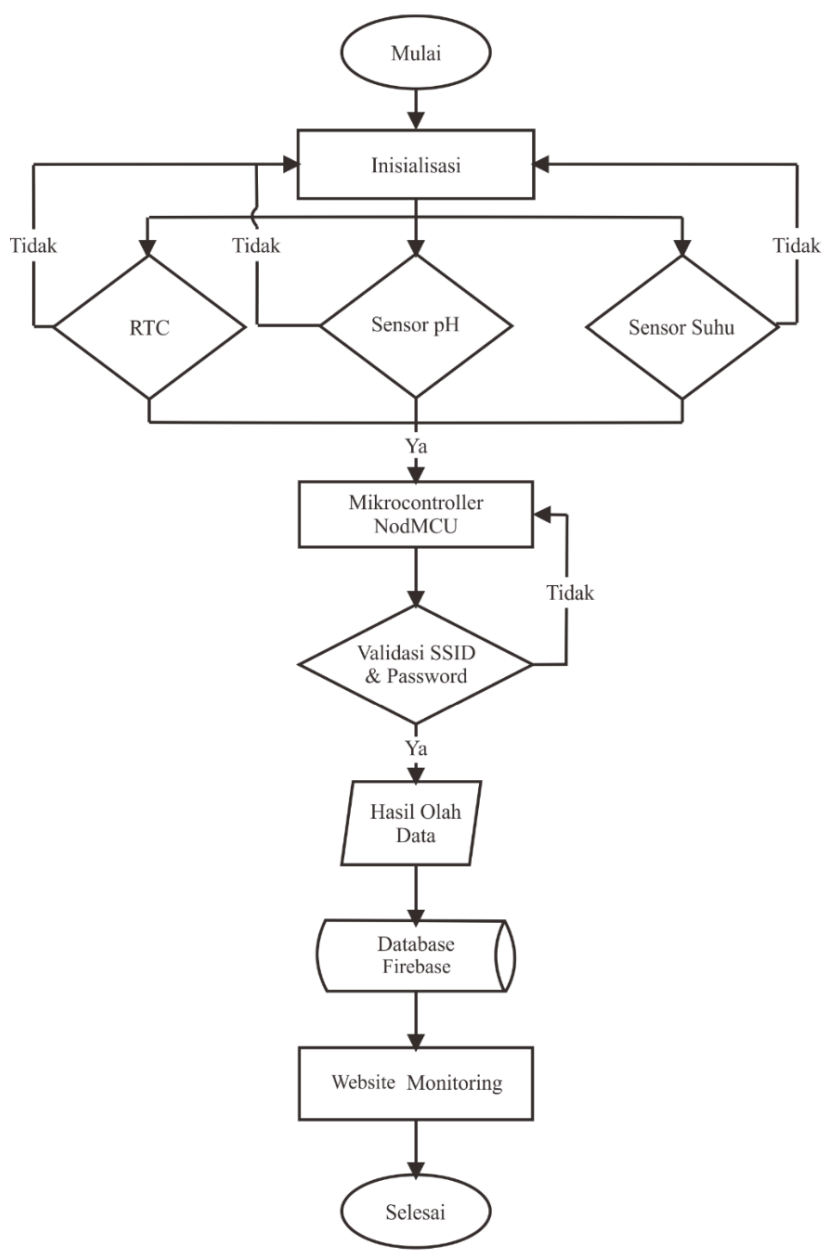

Gambar 2 Alur proses prototipe

Gambar 2 menunjukkan bagaimana alur kerja dari perangkat keras yang digunakan dalam penelitian ini, meliputi sensor, wifi sampai dengan website. Alur kerja dari perangkat 
lunak adalah dimulai dari pembacaan sensor untuk mengambil data yakni suhu, $\mathrm{pH}$ dan status dari lampu. Data-data tersebut akan dikirimkan ke server sampai dan ditampilan melalui halaman web.

Rangkaian elektronika diperlukan khususnya digunakan dalam pengaturan lampu dan untuk menghubungkan sensor-sensor pembaca kondisi aquarium. Perangkat mikrokontroler Arduino yang memberikan informasi menggunakan modul wifi NodeMCU sebagai pengirim data melalui internet sehingga pemantauan dapat dilakukan dengan menggunakan halaman web. Gambar 3 merupakan rancangan skema yang digunakan dalam penelitian ini. Dari rangkaian ini pula data yang ada pada aquascape diambil dan dikirimkan ke server serta disimpan dalam basis data Firebase. Satu tabel digunakan untuk menyimpan data yang diambil dari aquascape. Tabel ini berisi data waktu, suhu, $\mathrm{pH}$ dan status lampu.

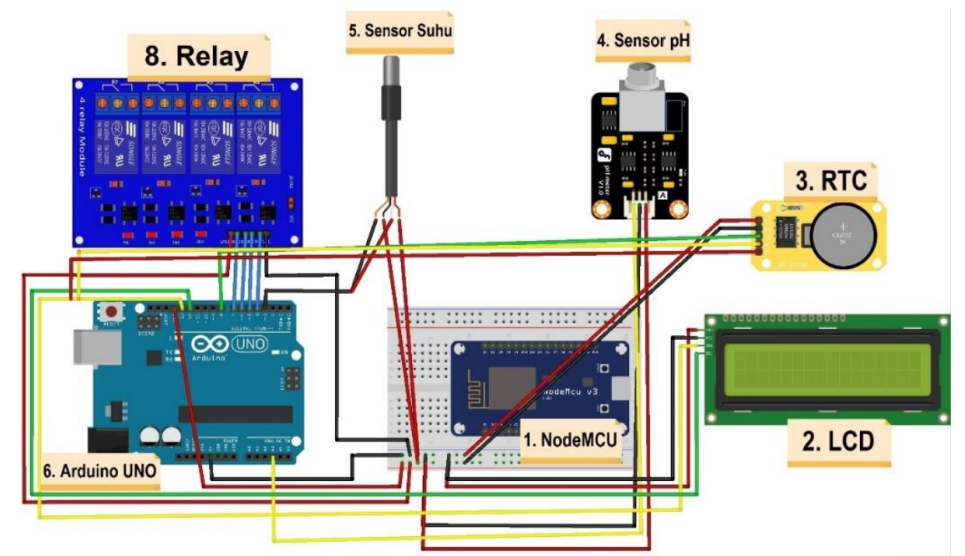

Gambar 3 Rangkaian skema elektronik

Proses pengujian prototipe yang dikembangkan dalam penelitian ini dilakukan dengan mengamati berbagai kesesuaian data yang dibaca oleh sensor, proses pengiriman data, penyimpanan data dan pengambilan data dari basis data sampai ditampilkannya di halaman web. Proses pengujian sistem meliputi, koneksi NodeMCU dengan wifi, pengaturan lampu, pembacaan suhu, tingkat keasaman dan komunikasi antara NodeMCU dengan Arduino.

\section{Hasil dan pembahasan}

Penelitian ini menghasilkan prototipe alat dan website yang digunakan untuk pengendali dan pemantau kondisi aquascape secara daring. Situs web pengendali prototipe mampu menampilkan perubahan informasi status sensor dan dapat melakukan pengendalian atau penjadwalan status lampu yang digunanakan sebagai penerangan aquarium. Menu utama yang ada dalam situs web adalah yang digunakan untuk pengendalian dan memantau keadaan lampu penerangan, $\mathrm{pH}$, dan suhu dalam aquascape. Tampilan dari menu utama ini adalah seperti terlihat pada Gambar 4.

\subsection{Pengujian}

Pengujian prototipe dalam penelitian ini dilakukan dengan mengamati kondisi yang dihasilkan oleh sensor dan status dari lampu yang dikontrol melalui halaman web. Pengujian pertama pada prototipe adalah dilakukan pada kendali otomatis lampu. Penjadwalan waktu hidup lampu dengan durasi tertentu dituliskan melalui halaman web. Pemberian perintah untuk 


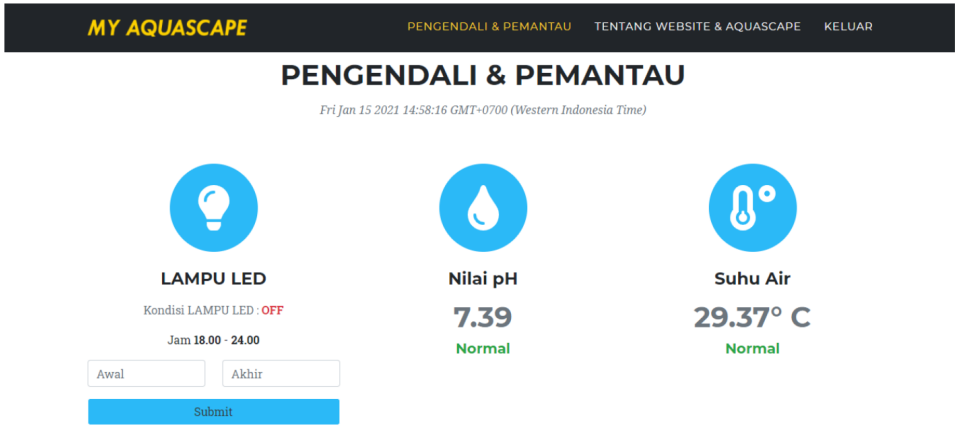

Gambar 4 Menu utama pengendali dan pemantau

mematikan dan menghidupkan lampu dilakukan dengan jarak waktu yang berbeda-beda. Hasil dari pengujian lampu ini terlihat pada Tabel 1.

Tabel 1 Pengujuian perintah pada lampu penerangan

\begin{tabular}{c|l|l|l}
\hline Percobaan ke- & Waktu awal & Waktu akhir & Kondisi \\
\hline 1 & $16: 48$ & $16: 49$ & ON \\
2 & $17: 02$ & $17: 05$ & ON \\
3 & $17: 11$ & $17: 20$ & ON \\
4 & $20: 56$ & $21: 25$ & ON \\
5 & $21: 36$ & $22: 35$ & ON \\
\hline \hline
\end{tabular}

Tabel 1 adalah hasil pengujian penjadwalan aktivitas lampu LED yang digunakan untuk memberi penerangan pada aquarium yang dilakukan melalui halaman web. Pengaturan waktu awal menentukan kapan lampu mulai menyala atau dalam kondisi ON dan waktu akhir sebagai penanda kapan lampu akan mati. Pada pengujian pengendali lampu yang dilakukan sebanyak 5 percobaan dengan 5 durasi yang berbeda seperti nampak pada Tabel 1 . Hasil pengujian didapatkan bahwa lampu berhasil dinyalakan dan dimatikan sesuai dengan waktu yang diberikan.

Pengujian kedua adalah pada sensor suhu pada prototipe alat juga menunjukkan keberhasilan namun memiliki masalah yakni adanya delay dari waktu pembacaan dan penampilan informasi di halaman web. Pengujian dilakukan dalam waktu dan kondisi suhu yang berbeda-beda, waktu perubahan suhu air dan waktu berubahannya status di web dicatat dan menunjukkan adanya waktu delay sebesar 33,13 detik terjadi pada pengujian sensor suhu ini. Hasil dari pengujian suhu dalam penelitian ini, selengkapnya tertampil pada Tabel 2.

Tabel 2 Pengujuian sensor suhu

\begin{tabular}{c|l|l|l|l|l}
\hline \multirow{2}{*}{ Jenis air } & \multicolumn{2}{|c|}{ Pengujian } & \multicolumn{2}{c|}{ Output di web } & \multirow{2}{*}{ Delay (detik) } \\
\cline { 2 - 5 } & ke & waktu & suhu ${ }^{\circ}$ C & kondisi & \\
\hline \multirow{2}{*}{ Air biasa } & 1 & $14: 51$ & 27,06 & Normal & 31,24 \\
& 2 & $15: 06$ & 27,00 & Normal & 32,48 \\
& 3 & $15: 21$ & 27,00 & Normal & 31,83 \\
Air panas & 4 & $14: 58$ & 70,12 & Tidak Normal & 32,31 \\
& 5 & $14: 11$ & 54,38 & Tidak Normal & 27,92 \\
& 6 & $15: 24$ & 45,25 & Tidak Normal & 34,07 \\
Air dingin & 7 & $15: 01$ & 8,192 & Tidak Normal & 33,07 \\
& 8 & $15: 15$ & 12,63 & Tidak Normal & 43,20 \\
& 9 & $15: 28$ & 15,81 & Tidak Normal & 32,07 \\
\hline
\end{tabular}

Pengujian ketiga adalah pada sensor pH, dimana dalam aquascape kualitas air merupakan 
hal yang sangat berpengaruh untuk keberlangsungan hidup habitat air. Nilai pH terlalu rendah atau terlalu tinggi, dapat menyebabkan kerusakan dan kematian dalam habitat aquascape serta menghambat proses reproduksi [9]. Dalam pengujian sensor $\mathrm{pH}$ yang dilakukan adalah dengan memantau nilai $\mathrm{pH}$ air pada aquascape apakah prototipe mampu mengambil, mengirimkan, menyimpan dan menampilkan data ke halaman web.

Pengujian sensor dilakukan dengan 3 bentuk percobaan. Percobaan pertama yaitu pengujian sensor keasaman dengan memberikan air yang memiliki nilai $\mathrm{pH}=7.0$, maka informasi yang tertampil pada web adalah "Netral". Percobaan kedua yaitu pengujian sensor $\mathrm{pH}$ dengan air yang telah diberi larutan larutan buffer asam dari pengujian tersebut nilai $\mathrm{pH}$ dari aquascape adalah 5,96 yang artinya kondisi air aquascape itu asam, maka informasi yang tertampil pada web adalah "Asam". Percobaan terakhir yaitu pengujian sensor $\mathrm{pH}$ dengan air yang telah diberi larutan buffer basa dengan nilai $\mathrm{pH}$ dari adalah 8,41 dan prototipe mampu menghasilkan informasi di web bertuliskan "Basa".

Dari hasil pengujian sensor $\mathrm{pH}$ tersebut nampak bahwa prototipe alat pembacaan sensor pH telah mampu bekerja dan menampilkan informasi ke situs web sesuai yang diharapkan. Namun dari hasil pengujian seperti juga pada pengujian suhu didapatkan adanya waktu delay untuk menampilkan informasi di web pada saat terjadi perbahan pembacaan sensor $\mathrm{pH}$ di aquarium. Rata-rata waktu delay adalah sebesar 31,77 detik yang dibutuhkan untuk bisa menampilkan perubahan status keadaan air ke halaman situs web.

\section{Kesimpulan}

Berdasarkan hasil pengujian prototipe alat pengendali atau penjadwalan mampu menjalankan fungsinya dengan baik. Pengendalian lampu, pembacaan sensor suhu dan tingkat keasaman air serta serta menampilkan informasi melalui halaman web dapat bekerja seperti yang diharapkan.

Namun masih ditemukan delay pada pembacaan dari prototipe ke sistem basis data Firebase yang kemudian ditampilkan pada halaman web. Rata-rata waktu delay pembacaan pada sensor $\mathrm{pH}$ 31,77 detik dan sensor suhu 33,13 detik. Penggunaan dua mikrokontroler untuk membaca data dan komunikasi untuk mengirimkannya ke basis data Firebase dimungkinkan menjadi penyebab adanya delay. Penelitian lanjutan yang bisa memperbaiki kekurangan ini perlu dilakukan untuk memperbaiki kekurangan yang didapatkan.

\section{Pustaka}

1 F. Panduardi dan E. S. Haq, "Wireless smart home system menggunakan raspberry pi berbasis android," Jurnal Teknologi Informasi Dan Terapan, vol. 3, no. 1, pp. 320-325, 2016.

2 R. H. Hardyanto dan P. W. Ciptadi, "Konsep "aqu pintar" aquarium pintar 4.0 berbasis iot," in Seri Prosiding Seminar Nasional Dinamika Informatika, vol. 3, no. 1, 2019.

3 P. V. Ertyan, P. Pangaribuan, dan A. S. Wibowo, "Sistem monitoring dan mengontrol aquarium dalam pemeliharaan ikan hias dari jarak jauh," eProceedings of Engineering, vol. 6 , no. 2, 2019.

4 D. Y. Tadeus, K. Azazi, dan D. Ariwibowo, "Model sistem monitoring ph dan kekeruhan pada akuarium air tawar berbasis internet of things," METANA, vol. 15, no. 2, pp. 49-56, 2019.

5 R. B. Pambudi, W. Yahya, dan R. A. Siregar, "Implementasi node sensor untuk sistem 
pengamatan ph air pada budidaya ikan air tawar," Jurnal Pengembangan Teknologi Informasi dan Ilmu Komputer e-ISSN, vol. 2548, p. 964X, 2018.

6 M. Hidayat dan N. Mardiyantoro, "Sistem pemantauan dan pengendalian ph air berbasis iot menggunakan platform arduino," Jurnal Penelitian dan Pengabdian Kepada Masyarakat UNSIQ, vol. 7, no. 1, pp. 65-70, 2020.

7 F. A. Prasetyo, "Rancang bangun smart fish berbasis iot menggunakan aplikasi blynk," 2018.

8 T. Widjaja, Aquascape: pesona taman dalam akuarium. AgroMedia, 2013.

9 A. G. Putrada, N. A. Suwastika et al., "Implementasi dan analisis pengurasan otomatis aquascape berdasarkan kualitas air menggunakan fuzzy logic," eProceedings of Engineering vol. 6, no. 1, 2019. 